\title{
24
}

\section{Kuk 1991 to 1998, the Station Abandoned and the Land Resumed: Archaeological Implications}

\author{
Jack Golson and John Muke
}

\section{Introduction}

Chapter 23 has told how major fieldwork at Kuk Station stopped in 1977 to give time for members of the Kuk Project to catch up with the data they had collected and see to other commitments. It was clear that the site had much more to give than it had already given. In these circumstances, Jack Golson, sometimes with others, paid short annual visits to Kuk to undertake specific pieces of work and keep in touch with Station developments and with the local community. No firm plans for renewing the Project had been made when the Agricultural Research Station was unexpectedly earmarked for closure at the end of 1990. This chapter discusses the uncertain situation that now followed for both the local community and the Project, given that the Papua New Guinea (PNG) Government still held legal possession of the land. In late 1995, however, its traditional owners began to move across the old Station boundaries, radically changing relationship between the Kuk community, the Kuk site and the archaeologists who wished to continue work there.

\section{Prelude: 1991-1995}

Jack Golson was at Kuk in August 1990 when Martin Gunther, the Officer-in-Charge over the previous 10 years, told him of the impending closure of some of the research stations of the Department of Agriculture and Livestock, as the Department of Primary Industry was now called. The reason for this was the suspension of operations the previous year at the Panguna mine on Bougainville, which had become a target of the secessionist Bougainville Revolutionary Army. By the time of its closure and after 15 years of operation, Bougainville Copper managing director reckoned that the mine had provided 40-50 per cent of PNG's foreign earnings and 15-20 per cent of revenue (cited by Denoon 2000: 192-193). Of the two highlands research stations, Aiyura, near Kainantu, and Kuk, it was anticipated that Kuk would continue because of recent investment in housing and facilities there.

In the event it was Aiyura that survived, on the grounds of perceived security problems for staff at Kuk. However, the Western Highlands Provincial Government was interested in the housing and the land. Consequently, before his departure, OIC Gunther (pers. comm., 2006) negotiated the transfer of the Station to the provincial administration for 'mothballing' for three years from 
January 1991, after which the Department of Agriculture and Livestock would decide what to do with it. The mothballing consisted of renting Station houses to staff from a variety of government departments in Mount Hagen and district, with some of the money going to the local community (cf. Muke 1998: 73; 2000: 99). However, trouble resulted from this arrangement, so the public servants were withdrawn, with the result that locals moved illegally into the houses to replace them. There was no intervention by government authorities in Mount Hagen, so essentially the Kuk Research Station was abandoned. Continued official inaction led in time to the traditional owners challenging the State by taking back the land that had originally been purchased from them (Ketan 1998: 20-21; Muke 1998: 76-79; 2000: 111).

The events leading to the abandonment of the Station took place in 1991 and 1992, when John Muke was doing graduate studies in the United Kingdom. In both years Golson, passing through Mount Hagen on his way to Southern Highlands Province, was dissuaded from visiting Kuk on the grounds that safety could not be guaranteed. In 1993 Muke was back in PNG, planning work for November with students of the University of Papua New Guinea at archaeological sites in his home district of Minj in the middle Wahgi Valley, including the Kana site (Muke and Mandui 2003). He invited Golson to join him. The plan was to try to pay a visit to Kuk at the same time, to see what the situation was and assess the prospects for future scientific work there. In October 1993 Muke, with Nick Araho from the PNG National Museum, visited Kuk to prepare the way.

The first thing Golson needed to do on arriving at Kuk after an absence of three years was to make contact with the people with whom he had developed close relations during the work of the Kuk Project in the 1970s and 1980s. Because most of this work had taken place in the eastern part of the Station, his closest relations were with the Kawelka Mandembo clan, which had land north and south of the easternmost Station blocks. There were two men of the clan who had been particular friends of the Project, the established big-man Ongka and a younger man Ru, both of whom were long-time friends and informants of the anthropologist Andrew Strathern (Strathern and Stewart 2000a for Ongka and 2000b: Part III for Ru).

Walking through the old Station the first day of their visit, Muke and Golson found the Station houses in the southwestern part occupied by locals, as they had been told. But they were surprised to see Ongka's lineage working gardens in blocks E8 and E9 in the northeast part of the Station on the lower slopes of Ep Ridge. At this stage, these were the only people to have crossed the boundary to occupy Station land, as distinct from buildings. They had not built houses there, only a small bush-materials church, from memory some $20 \mathrm{~m} \mathrm{x} 8 \mathrm{~m}$, in block E9. Ongka offered this as a venue for the public meeting about the future of Project work at Kuk that they had come to discuss with him and others.

Having had a favourable reception at Kuk, they went on to Mount Hagen to tell relevant people in the Western Highlands provincial administration about the forthcoming meeting. There they were informed that the head office of the Department of Agriculture and Livestock in Port Moresby had decided to reopen the Kuk Station the following year. If this were indeed the case, it meant that their planned meeting with Kuk people would be taking place at just the right time. The provincial administration agreed that two of its agricultural officers would come with them to the meeting in Ongka's church, as well as one officer from Cultural Affairs and Tourism.

On the day of the meeting, the little building was full to overflowing, though things were so busy for us inside and outside it that neither of us made a count. Proceedings lasted several hours, with many expressions of anger against the government directed at the three local officials who were present. The Station land, people said, had been Kawelka land before it had been sold to the government, which had not only paid too little for it, but had now abandoned it. As a result, the community had to take on the responsibility of looking after it, because the government had failed in its duty to do so. When the agricultural officers announced to the meeting that 
it had been decided to reopen the Station the following year, people declared that this would only happen if the community were compensated for having looked after the land following the government's abandonment of it.

These were the matters of major concern to people at the meeting, but Golson and Muke were able to say something about the Kuk Project, the widespread interest that there was in it and their hope that the work could continue, with the possibility of benefits flowing to the local community from its continuation. People were curious about what these benefits might be and the tourism officer said that the provincial administration might be ready to help from the tourism point of view. In general, the meeting left them confident that there was community support for the Project and its continuation.

In June 1994, Golson was again in the highlands working with Muke near Minj and they paid another visit to Kuk. There was no sign of Kuk Agricultural Research Station being reestablished. A government plan to set up a police post at Kuk and hand over the Station land to the Department of Forestry had come and gone. By contrast, there was a lot of nongovernmental activity. A Jika ${ }^{1}$ big-man, who had taken over Martin Gunther's former house in the very southwest corner of the property, had set up a vehicle workshop there. The playing field near the old workmen's compound a few hundred metres to the north was totally covered with plastic sheeting on which coffee beans were ripening. Two young men were operating a portable sawmill on the eucalypts that the Station management had planted, along its grid of road drains, for their capacity to soak up water from the swamp (cf. Mandui 1998: 47). People were cutting the cane grass growing widely across the eastern blocks for building purposes. Ongka's gardens in blocks E8 and E9 were well advanced.

A year later, in June 1995, Andrew Strathern, who by this time had joined the University of Pittsburgh, was at Kuk with a BBC team led by Charlie Nairn making a film, A Death to Pay For (Nairn 1996), about a compensation case involving the Kawelka. He reported to Golson, when they met in Sydney three months later, that no government official ever visited the old Station. Pigs were regularly invading the property along the drains leading from the boundaries, breaking down drain walls and blocking drainage. The felling of trees along the Station roads was now a commercial operation, with trucks coming in to carry the timber away, damaging roads and bridges on the old Station and the access routes to it. Andrew Strathern and Pamela J. Stewart, also of the University of Pittsburgh, saw further stages in this process while on periodic anthropological fieldwork in the Kuk area from 1996 to 1999, based at Ru Kundil's settlement. They kept in touch with Golson and his PNG colleagues.

Though the locals still recognised the Station as government land, they now considered it truly abandoned and were considering their options. In preparation for staking future claims, Kawelka clans on the southern side, Gorecki's South Kuk (Chapter 23), had put up fences north into Station land from its southern boundary and some of them were talking about consolidating this by moving residences across the boundary. Strathern said that there was an air of urgency about this activity because of possible preemption by rival claimants. Thus, recently, the Kawelka had refused to meet compensation claims for the killing of a Mokei man by giving rights to land at Kuk, as the Mokei had requested, and insisted on paying in money and pigs instead (Strathern and Stewart 1998a: 91). In addition, there were increasing stresses in the Kuk community (Chapter 23, section 'Discussion'). Among these were the competing requirements of land for subsistence and cash cropping, which would make a move into vacant Station land an attractive proposition (cf. Moutu 1998: 32-34).

1 On the spelling of tribal names see 'Note on Melpa orthography' in Chapter 22. 
The anthropologist Marilyn Strathern, who was on a visit to Kuk at the end of 1995, confirmed to Golson the information about the repossession of Station land beginning around that time, when they met at Cambridge University in mid-1996. When Muke was at Kuk with a Japanese film crew in November 1996, the repossession of the land was being consolidated through house building and gardening. This was a new phase in the Kuk story (Muke 1998: 81-82), which the authors call Phase 8.

\section{Phase 8 at Kuk}

In the light of these decisive developments, there was the need for another visit to Kuk to assess the prospects for renewed research in the newly changed conditions of landuse and landholding. Golson and Muke made that visit on 3-4 May 1997. Golson flew to Port Moresby on 2 May, staying overnight with Pamela Swadling, Chief Curator of Prehistory at the National Museum, to whom he promised to report on the Kuk visit. Muke and Golson flew to Mount Hagen the next morning, holding preliminary discussions at Kuk on the first day and making a site inspection on the second. This inspection took place on land allocated to Ru and his family and was carried out with Ru accompanied by two or three former Project workmen. Golson wrote a short report on the operation when he got back to Canberra, sending a copy to Swadling, as promised, and one to Muke (1998: 75).

\section{The Golson report}

Golson's report (Muke 1998) noted that the reoccupation of the old Station land had been most systematically carried out by its traditional owners, using the grid of Station roads and drains to arrange land allocation down to family level (cf. Moutu 1998: Fig. 1). A good proportion of the land resumed was under cultivation. In the time available, detailed inspection was limited to the southeastern blocks A8-12, where most of the archaeological work of the 1970s had been done and on which any future work was likely to concentrate. The food gardens in this area, as indeed elsewhere, could be expected to have destroyed the surface and near-surface evidence of houses and cultivations belonging to the two most recent agricultural phases at the site, Phases 5 and 6 . As well as more deeply buried evidence from these two phases, that of the earlier Phases 1-4 should on the whole not have been disturbed, except by the roots of coffee and other planted woody species. Moreover, not all of the ground in the A8-12 blocks had been fully cleared of its swamp grass cover, and some of these uncleared areas were archaeologically important locations for future excavations, if they could remain uncleared or at least uncultivated for long enough. The document then went on to propose a plan for fieldwork in these circumstances, noting Ru's point that this would require the agreement of every individual to whom any ground requested for excavation had been allocated in the process of repossession. Muke (2000: 112) subsequently reckoned that there were more than 50 landholders on the blocks of particular interest to the archaeologists.

Golson's report arrived at the museum at a time when its director, Soroi Eoe, was preparing for a UNESCO meeting in July 1997 at the Fiji Museum in Suva, at which he was planning to make two nominations for World Heritage listing on behalf of PNG: the coral terraces of the Huon Peninsula at Bobongara (illustrated in Swadling 1981: 2-3), and the Kuk site. To be eligible to make the nominations, PNG registered its acceptance of the World Heritage Convention the same month. The context of these nominations is considered in Chapter 25. Here we are concerned with the implications of the new situation at Kuk, as described in Golson's report, for the Kuk nomination itself. 
To investigate the new situation in detail, the museum sent a team to Kuk from 23-30 May 1997 to make an on-site assessment of the extent of the impact that repossession of the Kuk Station would have on the archaeological features of the site. This assessment was to take into account views about the heritage aspects of the site on the part of the Kawelka who had repossessed it.

\section{The National Museum report}

The PNG National Museum team consisted of Nick Araho and Herman Mandui of the Department of Prehistory at the museum and Andrew Moutu of the Department of Anthropology there, together with Muke from the university. Reports by Moutu (1988) on 'The Kuk archaeological heritage and the Kawelka landowners: An anthropological view of some pertinent issues' and by Mandui (1988) on 'Kuk Swamp at present - technical considerations' were submitted by Director Eoe at the Suva meeting, together with a nomination document drawn up by Golson and Pamela Swadling, Chief Curator of Prehistory at the museum. In Chapter 25, the section 'World Heritage listing' will show how all these documents came to be published in a volume headed by Andrew Strathern and Pamela J. Stewart (1998a), with additional chapters by Araho (1998), Muke (1998), Stewart and Strathern (1998) and Strathern and Stewart (1998b). The volume was intended to show 'some elements of the complexities that surround issues to do with cultural heritage generally, in cases where a delicate balance has to be sought between international, national, provincial, and local interests' (Strathern and Stewart 1998b: Preface and Acknowledgments).

\section{The local context}

At Kuk, the complexities referred to by Strathern and Stewart began with Kawelka repossession of the Station land. As Muke explains (1998: 71; cf. Moutu 1998: 22-23), the Kuk Project had started on government land in the colonial period in the early 1970s; even after PNG independence in 1975 the Station was run by expatriate Officers-in-Charge, under whom things continued as before. Over the years, the Project team won respect and friendship in the Kuk community and so proceeded without local hostility. At no time did Project members have to confront the original landowners over access because the State was owner of the land. This situation changed with its repossession. It was now the traditional owners who had the power to say yes or no.

Ru summarised the situation in a conversation with Muke, which Muke (1998: 83-84) translated from the original tok pisin as follows:

You want us to look after these things of the ancestors, and this is an issue to discuss in future. Now the Kawelka are short of land and have divided the blocks among themselves. It is hard for me to try and stop them from destroying the prehistoric sites. You know when they have already made their gardens, they will ask you for money if you want to excavate on their land.

Moutu (1998: 34) has pointed to intergenerational conflict on the question of the use of land containing prehistoric remains, the younger generation being much less sympathetic to the preservation of such evidence. He saw two reasons for this: first, because the main research at Kuk had taken place when the present young people were children; and second, because they 'were not educated about the history of their own place and people'. This made him pessimistic about the prospects for 'a mutual compromise' (1998: 36) to save the archaeological heritage at Kuk without a concerted effort of dialogue and education in the local and wider context (1998: 36-38). Muke too (2000: 112) reported that 'only a significant effort at public education 
[would] change the attitude of the people' in a situation where the possession of the cultural resource was weighed against the economic value of the swamp by way of the cash crops that could be grown there.

There are many factors to take into account when considering these questions, some specific to Kuk, others general to highlands populations. Though the Kuk Research Station was established on Kawelka land in 1969, Kawelka men were not given preference in employment during the development phase of the next few years, when it was provided with its grid of drains and roads (as described in Textbox 6.1). The policy was that the labour force should not be dominated by any one group, though at least one early Officer-in-Charge saw advantages in hiring and housing men with no local ties and obligations that might interfere with their regular and full-time attendance at work.

Beginning in 1972, the Kuk Project overlapped this developmental stage and so initially required labour for removing swamp vegetation and digging drainage ditches in the eastern half of the Station where it was to operate. Golson's labour force for this work was haphazardly recruited. It began with three young Hageners, two of them English-speaking, who had worked with Australia-based academics in the recent past. They brought men from their own groups with them when taken on by Golson, while other men were attracted to the Station by the prospect of work and presented themselves for employment on the spot. Again, Kawelka were underrepresented in the Project as in the Station workforce, though for different reasons, and Golson was quickly made aware of this by the Kawelka whom he had hired. He moved to correct the situation when, after a few weeks during which the workforce spiralled to around 40, the preparatory work of grass cutting and drain digging was finished on block A9 and there was need for less labour. From this point on, Kawelka came more and more to provide labour, in the first season and in subsequent years.

In these circumstances, and with men who were increasingly likely to be working directly with archaeologists or other Project specialists, it was possible to sit down and talk about what the Kuk Project was all about. The men identified many of the archaeological features that were being exposed both in plan in excavation trenches and in profile in drain walls, because they were familiar with them in their everyday life: garden ditches, house floors and the stakeholes, postholes and cooking pits associated with the two areas of activity. Both drain diggers and excavators would from time to time encounter agricultural tools of wood preserved by the swamp waters, some of them of types no longer in use, as well as stone axe blades and fragments of them. Everyone recognised what such things were and the older men knew how to use them (cf. Steensberg 1980: Chapters 1 and 2; cf. Chapters 19-21 here).

The Project benefited greatly from conversations about these and other matters that came up in the course of investigations, but what team members were unable to convey was a sense of the chronology of the site and their interest in the relationship of gardening systems of different ages. This was in great contrast to their experience with the literate and numerate students who came to visit in groups from Mount Hagen High School and the Highlands Agricultural Training Institute at Korn Farm just out of town. Nevertheless, Project workmen and the Kuk community at large were in agreement that the Kuk Project had to do with the work of the ancestors, samting bilong tumbuna, and in that we had a common cause. There was quiet satisfaction locally that the name of Kuk was becoming widely known (Kuk i gat bik nem). As regards the workmen specifically, they said that they were also happy to work for the Project because they were not shouted at as they were on plantations. In November 1972, towards the end of the first season, on their own initiative, some of them gave a broadcast in Melpa on Radio Hagen about their work. 
With this background, the various visits and discussions of the 1990s that have been described helped to 'open the road' for a new phase of archaeological research in 1998 and 1999 (cf. Strathern and Stewart 1998a: 93). The direction of this research was in the hands of ANU doctoral student Tim Denham, and it formed the basis of his dissertation (Denham 2003a).

Denham had no difficulty in recruiting labour for his excavations, mainly men who had worked for the Kuk Project in the past. Predictions in Golson's 1997 report that the earlier layers at the site would not be affected by the subsistence gardening of the new inhabitants of former Station land proved accurate. The location of excavations and compensation for such use of land were harmoniously negotiated by Denham with the new landholders. However, the PNG National Museum's 1997 decision to nominate Kuk for World Heritage listing had already put the matter in an arena where wider issues were at play. This had serious implications at the local level, as discussed in Chapter 25.

\section{Acknowledgements}

Thanks are due to Martin Gunther for information about the circumstances, general and local, in which the Kuk Agricultural Research Station, of which he was the last and longest-serving Office-in-Charge, came to an end. 
This text is taken from Ten Thousand Years of Cultivation at Kuk Swamp in the Highlands of Papua New Guinea, edited by Jack Golson, Tim Denham, Philip Hughes, Pamela Swadling and John Muke, published 2017 by ANU Press, The Australian National University, Canberra, Australia. 